\title{
Does Country Attractiveness Matter in International Competition? The Case of Countries' Bidding to Host Major Sports Events
}

\section{Kwang-Hoon Lee \& Jean-Loup Chappelet}

To cite this article: Kwang-Hoon Lee \& Jean-Loup Chappelet (2021): Does Country Attractiveness Matter in International Competition? The Case of Countries' Bidding to Host Major Sports Events, International Journal of Public Administration

To link to this article: https://doi.org/10.1080/01900692.2021.1879851

\section{曲 Published online: 10 Feb 2021.}

Submit your article to this journal $\widetilde{x}$

Q View related articles $\sqsubset$

View Crossmark data $\asymp$ 


\title{
Does Country Attractiveness Matter in International Competition? The Case of Countries' Bidding to Host Major Sports Events
}

\author{
Kwang-Hoon Lee ${ }^{\mathrm{a}}$ and Jean-Loup Chappelet ${ }^{\mathrm{b}}$

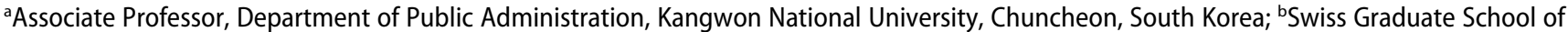 \\ Public Administration, University of Lausanne, Lausanne, Switzerland
}

\begin{abstract}
A country's attractiveness is a factor in its success in many areas of international competition, such as encouraging international investment, but its impact on international sporting events remains unexplored. Using various measurements of country attractiveness, statistical tests of the proposition that a country's economic, social, and environmental attractiveness are correlated with its success in bidding to host international sporting events were conducted using data on the results of competitions to host 54 world championships in Olympic sports/disciplines from 1990 to 2012. The results presented here affirm the impact of country attractiveness on the success of bids to host such events.
\end{abstract}

\section{KEYWORDS}

Country attractiveness; country marketing; sustainable development; sports event bidding; olympic World

Championships

\section{Introduction}

The hosting of sporting events has, over the past several decades, become such a prevalent vehicle for furthering the various interests of cities, regions, and countries (Bason, 2019; Chappelet, 2019) that competition between them to win the right to host major sporting events has become increasingly fierce (Chappelet \& Lee, 2016; Walters, 2011). Although the increasingly prevalent phenomenon of countries bidding to host major sporting events is a promising research topic in the field of international public administration, little effort has, to date, been devoted to understanding the phenomenon of bidding to host international sporting events. As sporting events are, in essence, "widely broadcast social events whose impact on their different audiences is linked to the result of the actions of the various participants, who are placed in a situation of achievement, performance or competition" (Ferrand, 1993), the "attractiveness" of a sporting event is crucial for its success. Therefore, it is important to investigate which countries tend to win this highly competitive race to "attract" international sports events.

Country attractiveness, which can be defined as "the degree to which a country is preferred to others in the eyes of its relevant stakeholders on the basis of certain criteria including tangible and intangible elements" (Lee, 2016), may play an important role in enhancing the success of countries in global competitions. For instance, country attractiveness is a key factor in a country's success in many areas of international competition, such as attracting international investment in a specific industry/market (Choi, 1999) or enticing international tourists/migrants to visit a specific touristic or residential destination (Aminuddin, 2010; Hu \& Ritchie, 1993). Given this context, the question of whether country attractiveness also plays a role in international competitions to host major sporting events arises.

Lee (2016) argues that the more relevant stakeholders, e.g., international investors/tourists/migrants, believe that a country will meet their needs by maximizing the benefits of investment/tourism/migration, the more attractive a country will seem as a host. As such, the hypotheses in this paper hold that the more event owners ${ }^{1}$ as stakeholders relevant to international sport-event bidding (Chappelet, 2016) believe a bidding country will maintain a specific level of sustainable development, the more likely it will be to be chosen as a host.

Scholarly attention must be paid to one of the most obvious areas in which countries are directly and fiercely competing with one another when bidding to host major international non-recurring sporting events (Turner \& McGillivray, 2018) because the attractiveness of a country as a form of "soft power" (Nye, 2004) may persuade sporting event owners to view a city/country as a favorable choice to host an event. Moreover, since

CONTACT Kwang-Hoon Lee swiss@kangwon.ac.kr @ Associate Professor, Department of Public Administration, Kangwon National University, ChunCheon Si, Kangwon Do, South Korea.

(c) 2021 Taylor \& Francis Group, LLC 
a bid is an overall offer from a city/country to a sport's governing body that is made to ensure consideration of it as a possible host for an event (Diaey et al., 2011), a country's attractiveness can be a useful signal (Spence, 1974) to an event's owner ("principal") because it conveys evaluative information about a bidding country's ("agent's") financial and organizational capacity to host a major sporting event successfully.

Thus, reflecting the perspective of sustainable development (World Commission on Environment and Development, 1987), this paper was written with a focus on the importance and impact of country attractiveness on the success of a country's bids to host international sporting events. The paper first includes a review of the landscape of previous literature on the importance and impact of country attractiveness on bids to win competitions to host international sporting events. Specifically, reflecting the integration of empirical evidence and related theories on signaling and soft power, research hypotheses are proposed and statistically tested using quantitative analytical methods. A discussion of the results follows, and, finally, the conclusion summarizes the findings and their implications.

\section{Literature review}

\section{The importance of country attractiveness in international competitions to host major sporting events}

The concept of country attractiveness, which has been developed in research on international business, tourism, and migration, can be integrated into the framework of sustainable development comprising economic, social, and environmental dimensions (Lee, 2016). The existing scholarship on the factors affecting the success of bids to host the Olympic Summer and Winter Games offers a possible clue regarding sporting event owners' main preoccupations regarding the economic, social, and environmental attractiveness of host countries. Thus, the purpose of writing this paper was to examine how country attractiveness affects international competitions to host international sporting events.

The reasons that the field of sports was chosen as the context for an examination of the multi-dimensional effects of country attractiveness, particularly in the case of countries bidding to host international sporting events, are two-fold: first, this area, as one of the most prominent international marketplaces, is roughly analogous to efforts to attract international investments in terms of the relationship between prospective host countries (i.e., event bidders) and foreign investors (i.e., event owners). In other words, the choice of a host city/country by an event owner (typically an International Federation) is comparable to an international investor's choice to locate its factories in a country. Indeed, a major event such as the FIFA World Cup or UEFA European Cup is the main "product/service" that is traded between an event owner and bidder in an international sporting event-bidding context, which tends to reflect "demandsupply" mechanisms through the owner's attempt to maximize revenue from broadcasting and sponsorship agreements. Thus, the concept of country attractiveness used in analyzing international business transactions may also be applied to the topic of this paper.

Second, bidding to host an international sporting event is different from a typical international investment in that it can be regarded as part of a market that does not simply operate according to the demandsupply mechanism but rather can be influenced by non-economic factors, such as the soft power of a country. In terms of the importance of the intangible (i.e., social and environmental) aspects of country attractiveness, bidding to host international sports events has a lot in common with international tourism and migration. This bidding system implies that an event owner can select the host country for international sporting events on the basis of the relative attractiveness of each country in social and environmental dimensions besides the economic one (i.e., "market attractiveness") because a potential host country must also be evaluated as a destination for international sporting events (i.e., "destination attractiveness"). Hence, this paper on bidding to host international sporting events is useful for validating the effects of a country's social and environmental attractiveness.

\section{The impact of economic factors of country attractiveness: A hypothesis based on signaling theory}

Due to the increased salience of economic motives for hosting sporting mega-events since the mid-1980s, no event owner today awards exclusive hosting rights without considering the economic interests or commercial logic of the global sporting marketplace, including the need to maximize the expected financial benefits and revenue from broadcasting rights (both on TV and the internet), official sponsorships, and other marketing programs (Poast, 2007; Toohey \& Veal, 2007).

Assuming that event owners consider potential host countries profitable markets, signaling theory (Spence, 1973) can address how a bidding country signals its ability to host a successful event in terms of providing economic profits to event owners via observable information 
regarding its economic achievements. This market-based explanation presumes a price mechanism of demand and supply in international sporting event markets, i.e., the selling and buying of hosting rights that takes place between event owners who choose host sites and event bidders who compete to host such events. Here, the quality of bids containing investment plans for sporting facilities and other organizational infrastructure is, in essence, difficult for event owners to assess because it cannot be known whether bidders will fully honor their initial promises. The competitive nature of the bidding process encourages bidders to make generous pledges with no ramifications and/or enforcement tools to ensure that such promises are honored. Thus, regardless of bidders' actual ability to successfully host such events, they have an incentive to exaggerate the attractiveness of their bids to defeat their competitors.

Moreover, as bidding processes for major international sporting events have become increasingly sophisticated and the bidding industry has become highly professionalized through the use of commercial bid consultants and companies, ${ }^{2}$ the characteristics of candidates' bids have converged into a set of ideals or best practices. In the face of such homogenization of the quality of bid proposals, event owners, however, receive little information about the actual status of bidders' unobservable attributes regarding the sophisticated nuances of successful hosting, which may result in unfavorable selections by event owners due to large discrepancies between bidders' seemingly promising proposals and their actual capacity to host such events. This information asymmetry between event bidders and owners may raise a moral issue (Dowse \& Flechter, 2018). In a so-called "market for lemons" (Akerlof, 1970), it is paramount for event owners to assess "who" is bidding, instead of only considering bid offers that have been tactfully deployed to attract event owners, to evaluate the reliability and feasibility of bidders' promises.

Thus, just as international investors evaluate potential host countries for FDI, a bidding country's economic records, based on information including market size (GDP - Gross Domestic Product), market growth (GDP growth rate), and purchasing power (GDP per capita), can be useful signals for event owners when deciding which are the most promising host venues in terms of financial revenue. In other words, because international sporting event owners may choose a host country based on signals of its economic viability to maximize the financial profits of holding major sporting events, countries that have large national economies, fast economic growth, strong purchasing power, and relatively open market environments may use their substantial tangible resources to strategically market their bids by promising economically successful games to event owners. Therefore, based on signaling theory (Spence, 1973), the first hypothesis is formulated as follows:

H1: If event owners choose hosts based on the signaling of bidding countries' economic attractiveness, they will be more likely to award permission to host their events to countries that perform well economically.

\section{The impact of the social and environmental factors of country attractiveness: $A$ hypothesis based on soft power theory}

While the Olympics were politicized by participating countries as a vehicle to demonstrate the superiority of their political regimes during the Cold War, it has been observed that, in the post-Cold War era, a country's social and political advantages, known as "soft power" (Nye, 2004), can affect the results of bidding competitions because the values of Olympism rest on its core elements (Lee, 2017; Lee \& Chappelet, 2012).

The fundamental principles governing the Olympic system include transparency, democracy, accountability, autonomy, and social responsibility (Chappelet \& KüblerMabbott, 2008), and "Any person or organisation belonging in any capacity whatsoever to the Olympic Movement is bound by the provisions of the Olympic Charter and shall abide by the decisions of the IOC (International Olympic Committee)" (International Olympic Committee (IOC), 2011, p. 14). Thus, one can posit that in bidding to host Olympic events, the bidding countries' social conditions, as the main components of soft power, can be assessed by their level of human development, transparency, and sporting success.

Moreover, according to Nye (2004), a country's soft power comes not merely from its domestic policies or bilateral relations with foreign countries but also from its participation in international treaties/agreements and global institutions, including observance of environmental norms, rules, and obligations regarding global warming (e.g., the Kyoto Protocol) (Li, 2009, p. 225). Several scholars have highlighted the importance of environmental responsibility in hosting sporting events (Cantelon \& Letters, 2000; Chappelet, 2008; Chernushenko, 1994; Leonardsen, 2007; Peiser \& Reilly, 2004; Pentifallo \& VanWynsberghe, 2012).

Today, sports organizations are beginning to embrace the belief that environmental issues are intertwined with social/cultural and socioeconomic issues (Ferrand \& McCarthy, 2009, p. 51). Chappelet (2008) argues that the IOC's official concerns about environmental protection, which have been fully integrated into Olympic rules 
and ideology, are not simply a sign of the times but have also become a positive, non-material legacy of the Olympic Winter Games since the 1990s, and the ecological components of the Olympic tradition as well as notions of sustainability through Olympism are applied at both the Summer and Winter Olympic Games today. In this regard, Lee and Jean-Loup (2012) have noted that environmental factors (e.g., air pollutant emission reduction) can also be one of core elements of soft power.

Thus, sporting event owners, who strive to remain legitimate in the eyes of stakeholders, and, more generally, "society," have, since the 1990s, emphasized the ecological legacy of their sporting events as the third dimension of Olympism (Chappelet, 2008). Thus, bidding countries have also followed the ecological guidelines set by event owners, although their observance of such environmental principles is seemingly unprofitable from an economic point of view.

For instance, event owners concerned about a country's environmental sustainability can advertise their concern about environmental protection to achieve organizational legitimacy in the global public sphere by incorporating environmentally sound practices into their statutes and policies and awarding permission to host their events to countries making efforts to address environmental issues rather than to those that allow the emission of harmful pollutants.

In turn, to encourage event owners to choose them as hosts, bidding countries must strive to attain legitimacy regarding environmental issues by demonstrating "desirable" behaviors and holding "Green Games" (i.e., eco-friendly sporting events). Accordingly, the better a country's environmental record becomes (e.g., by producing fewer greenhouse gas/air pollutants emissions or more renewable energy, etc.), the more attractive it becomes to event owners, who tend to gain legitimacy by expressing concern for the environment. Therefore, based on soft power theory (Nye, 2004), the second hypothesis is formulated as follows:

H2: If event owners choose hosts on the basis of the soft power stemming from their social and environmental attractiveness, they will be more likely to award permission to host their sporting events to countries that have good social and environmental records.

\section{Research design}

\section{Econometric model specification}

The hypotheses presented in the previous chapter are tested using quantitative methods that analyze country- level aggregate data. In order to examine the effects and relative influence of country-level factors on international sporting event-bidding success, the proposed predicative model specification was constructed as follows:

$$
\begin{aligned}
{\text { Bid } \text { Wins }_{i t}=}_{=} & \beta_{0}+\beta_{1} \text { GDP }_{i t-1}+\beta_{2} \text { GDP } \text { Growth }_{i t-1} \\
& +\beta_{3} \text { GDP per Capita } \\
& +\beta_{4} \text { MarketOpenness }_{i t-1} \\
& +\beta_{5} \text { Human Development }_{i t-1} \\
& +\beta_{6} \text { Sporting Success }_{i t} \\
& +\beta_{7} \text { Transparency }_{i t-1}+\beta_{8} \text { High } \\
& \text { Temperature }_{i t-1}+\beta_{9} \text { CO }_{2} \text { Emissions }_{i t-1} \\
& +\beta_{10} \text { Renewable Energy }_{i t-1} \\
& +\beta_{11} \text { PM }_{10} \text { Emissions }_{i t-1}+\beta_{12} \\
& \text { Military Expenditure }_{i t-1}+\varepsilon_{i t}
\end{aligned}
$$

Where the subscripts in the equation above denote each bidding country $i$ in time $t$, which is the number representing the year when the event owner's choice of the host country was made. Independent variables receive values from the year prior $(t-1)$ to when host selections were made given a time difference assumption that the event owners' decisions during election years were based on candidate countries' status during the previous year; $\varepsilon$, which is the unexplained part of the statistical estimation representing the stochastic error term, captures the effects of other remaining influencing factors (e.g., lobbying or improving the quality of a bid proposal by suggesting good technical solutions for the event).

\section{Dependent variable}

Regarding the measurement of a country's success in bidding to host international sporting events, "success" may be defined as a country's number of winning bids. Thus, the dependent variable, Bid Wins, represents how many events each country has won per year from $1990^{3}$ to 2012. The data cover all bids to host world championships in Olympic sports and disciplines ${ }^{4}$ at the international level except tennis ${ }^{5}$ and men's soccer. ${ }^{6}$ Accordingly, the bidding results of 54 world championships at the highest level, owned by 31 International Federations and including 24 summer and 7 winter sports, were collected from the official website of each sport's governing body as well as the Olympic Library in Lausanne, Switzerland (Appendix I).

\section{Independent variables}

To evaluate the relative influence of a country's economic, social, and environmental attractiveness on its 
bidding success in the context of major sporting events, the relevant independent variables may be measured by multiple indices with respect to the economic, social, and environmental dimensions of a bidding country. Considering the comparability and availability of the existing data, the author of this paper collected crossnationally comparable official statistics, which have been published annually by international organizations since the 1990s and cover all bidding countries.

First, a country's economic conditions were measured using several economic indicators encompassing the internal and external market potential of a country: on the one hand, from a domestic market perspective, $G D P$ (as a proxy of market size), GDP growth (as a proxy of market growth), and GDP per capita (as a proxy of a country's purchasing power to assess the weight of the population size and the quality of the market) were collected from the World Bank's World Development Indicator Database. On the other hand, from a foreignmarket perspective, the Market Openness of a country was assessed using the KOF economic globalization index, which measures 207 countries' actual economic flow, as well as economic restrictions, during the period between 1970 and 2010 (Dreher, 2006).

Second, a bidding country's level of social development was captured using several socio-cultural indicators, the first of which is Human development, which refers to the level of a country's human development (life expectancy, education, and income) as measured by the Human Development Index (HDI) in the Human Development Report published since 1990 by the United Nations Development Programme (UNDP). Following the example of McClory (2010) as well as that of Lee and Jean-Loup (2012), Sporting Success represents each country's sporting power as measured by the number of Olympic gold medals (Hoffmann et al., 2002) won in the previous Summer and Winter Olympic Games based on data gathered from the IOC. Based on the example of Poast (2007) and Feddersen et al. (2008), Transparency, which refers to a country's soft power in terms of ethics and anti-corruption measures, was measured using the Corruption Perceptions Index (CPI) produced by Transparency International.

Third, the level of environmental concern of each bidding country was measured using several environmental indices, one of which was High Temperature, ${ }^{7}$ a dummy variable based on the categorization of countries into two groups and taking a value of 1 if a country was located in a "hot" (i.e., tropical and/or dry) climate zone with a high temperature and 0 otherwise. This refers to the Köppen climate classification scheme, which is one of the most widely used climate classification systems and has been adopted in many climate studies and subsequent publications (Kottek et al., 2006). Next, $\mathrm{CO}_{2}$ Emissions and $P M_{10}$ Emissions measured a country's production of greenhouse gases and air pollutants such as $\mathrm{CO}_{2}$ (carbon dioxide) and $\mathrm{PM}_{10}$ (particle material 10 micrometers or under in diameter, or particles small enough to be absorbed in the deepest part of the lung) relative to GDP, respectively. Conversely, as a proxy for efforts to achieve environmental sustainability, Renewable Energy measures a country's total renewable electricity net generation. The data were collected from the World Bank's World Development Indicator Database and the U.S. Energy Information Administration (EIA).

In addition, as a control variable, Military Expenditure was used as a proxy to measure each country's military power using its annual military expenditures based on data collected from the World Bank's World Development Indicator Database. This variable was included in the model to test the realism hypothesis of the "mainstream" realist school of thought in international relations theory, which can be expected to assume that a country's hard power, i.e., military force, might also affect event owners' choice of event hosts. Methodologically, to assess the impact of soft power on international competition to host major sporting events, both soft- and hard-power factors must be included in an analytical model so that, while one factor is controlled, the influence of the other can be estimated (Lee \& Chappelet, 2012, p. 50). According to soft power theory, the effect of this variable can be expected to be insignificant or negative.

\section{Analytical methods}

This paper includes statistical analyses of panel datasets collected from each bidding country at several intervals between 1990-2011 (on bid wins, that is, a country's number of winning bids during a year). The estimation strategy of each regression method was chosen considering the characteristics of the data as well as the robustness checks of the estimation results.

The distribution of the dependent variable (Bid Wins) in the histogram in Figure 1, shown above, appears similar to the Poisson probability distribution that is appropriate to use on count data models ${ }^{8}$ (i.e., one that uses integers that are non-negative and discrete), such as the Poisson regression model (Cameron \& Trivedi, 2009; Hilbe, 2011; SCOTT \& Jeremy, 2006).

Figure 1 also shows that a value of zero cannot occur in the dataset of Bid Wins because countries that did not have any winning bids, by definition, cannot be counted according to this dependent variable; thus, in such data, the values begin with 1 without the possibility of a value of 0 . This dataset that has no value of 0 because 


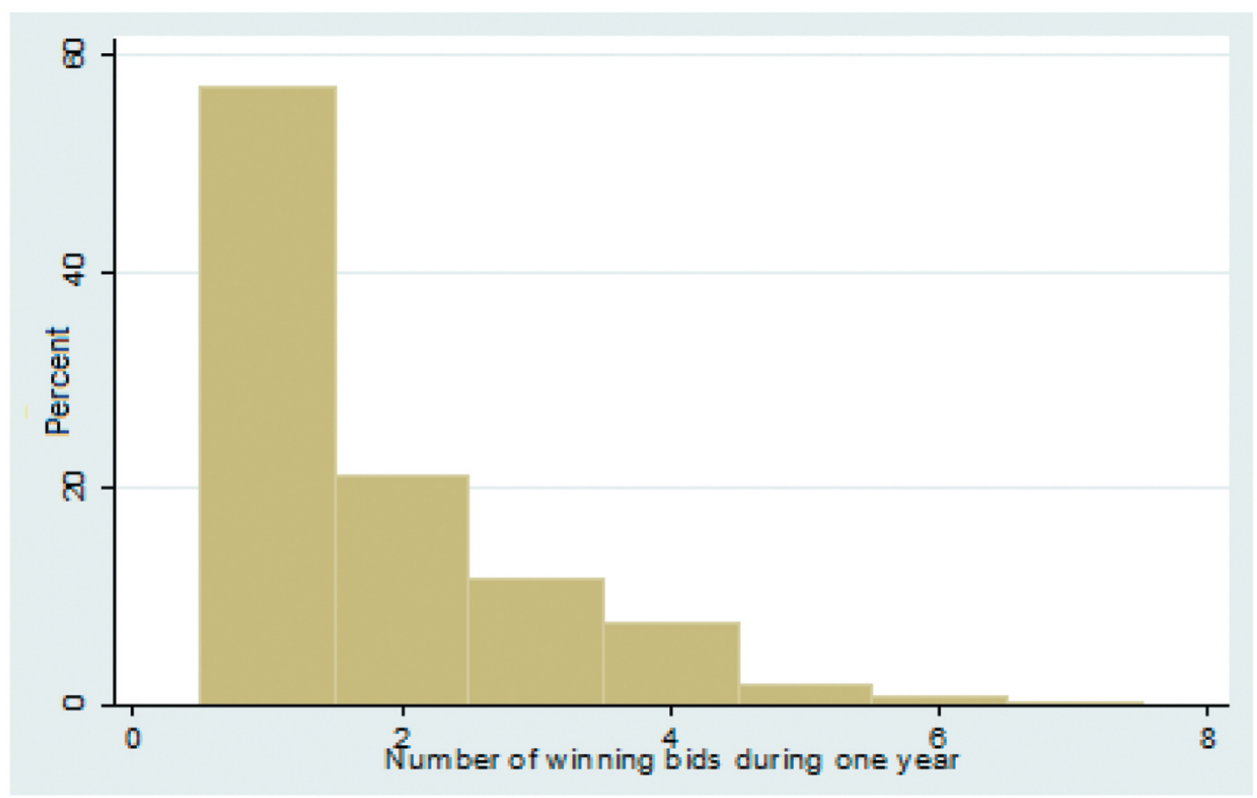

Figure 1. Histogram of winning bids.

observations enter the sample only after the first bid is won, ${ }^{9}$ which suggests that a model for truncated counts, such as the "zero-truncated" Poisson regression (SCOTT \& Jeremy, 2006), should be used. Considering the possibility of several underlying assumptions, such as "overdispersion" ${ }^{10}$ relative to the Poisson distribution and the nature of panel data, both a zero-truncated negative binomial model (Hilbe, 2011) and randomeffects $^{11}$ panel Poisson model (Cameron \& Trivedi, 2009) were also employed.

Thus, to construct three distinct data models that could be compared to one another, suitable regression analyses using various econometric methods, such as the zero-truncated Poisson, zero-truncated negative binomial, and panel Poisson (random-effects model) methods, were used. Calculations and statistical tests were performed using STATA SE version 11.0 software.

\section{Empirical results}

Table 1 shows the results obtained using the three regression methods mentioned above, including the zero-truncated Poisson, zero-truncated negative binomial, and random-effects panel Poisson regression. ${ }^{12}$ In all models, which were stepwisely regressed (Models 1-16), almost all independent variables associated with country attractiveness were significant and reflected the expected signs of their directions. Regarding a country's economic attractiveness, GDP was positively significant at $0.1 \% \sim 10 \%$ significance levels, and GDP per Capita as well as Market Openness were also significant and positive at $1 \% \sim 10 \%$ significance levels. However, GDP
Growth Rate was not significant at a conventional significance level. With respect to the social attractiveness of a country, Sporting Success was positively significant at $0.1 \% \sim 5 \%$ significance levels, as were Human Development, Transparency, and Political Stability at $0.1 \% \sim 10 \%$ significance levels. Concerning a country's climatic attractiveness, Tropics showed negative effects on the dependent variable at a 5\% significance level. $\mathrm{CO}_{2}$ Emissions and Particle Emissions were significant and negative at $1 \% \sim 10 \%$, while Renewable Energy was positively significant at $0.1 \% \sim 10 \%$ significance levels. Military Expenditure as a control variable was negatively significant at $0.1 \% \sim 5 \%$ significance levels. These results confirm the statistically significant effects of country attractiveness on SEHS success in major sports events (i.e., 54 world championships in Olympic sports).

\section{Discussion and conclusion}

The results obtained using various model specifications and measures constitute empirical evidence that confirms this paper's main hypotheses regarding the significant effects of country attractiveness on international sporting event-bidding success.

Specifically, countries had greater bidding success when they had larger market sizes (measured by GDP) and stronger purchasing power (GDP per Capita) as well as relatively open markets. ${ }^{13}$ This finding on the effect of the economic attractiveness of a bidding country suggests that international sporting event-bidding can be regarded as a sort of international sports market in which Olympic hosting rights, as well as Olympic brands 


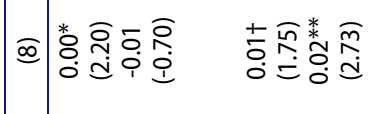

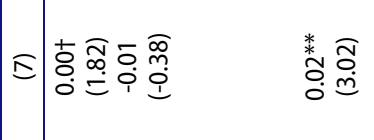

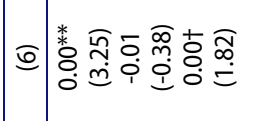

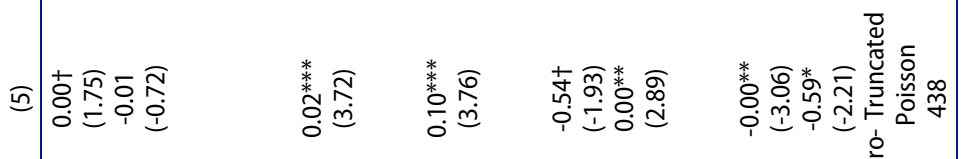

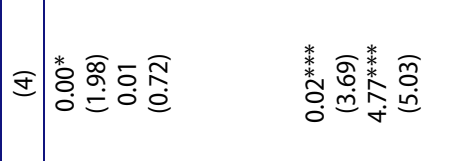

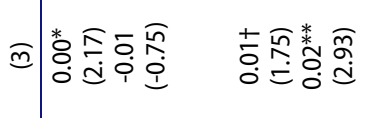

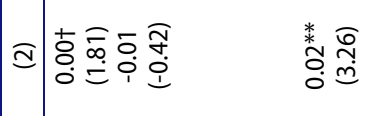

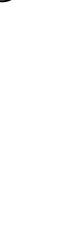

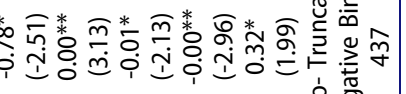

๙ᄄ

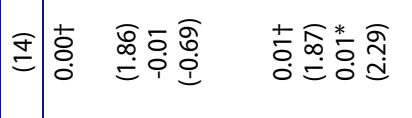

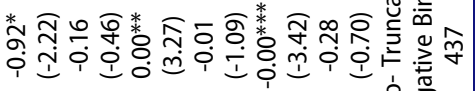

舀絭

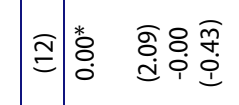

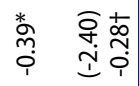

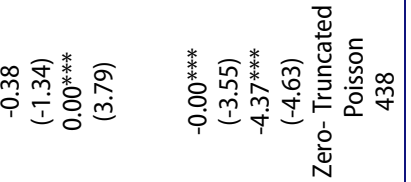

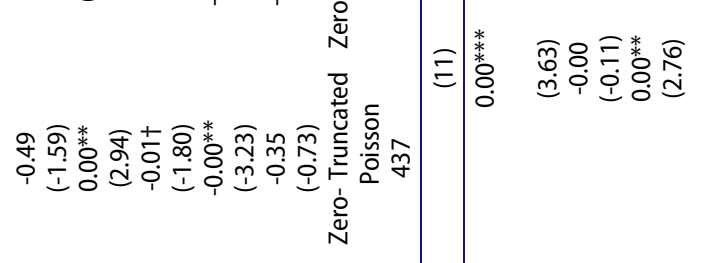

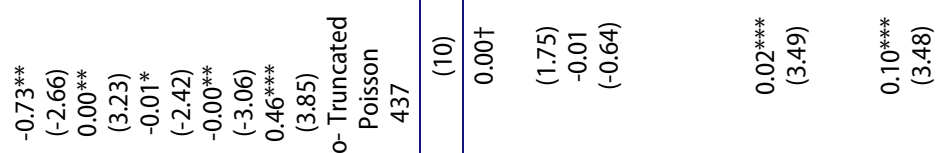

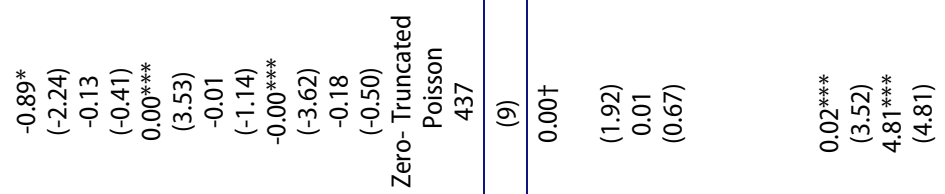

$\frac{\dot{s}}{\overrightarrow{5}}$

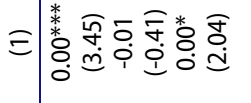




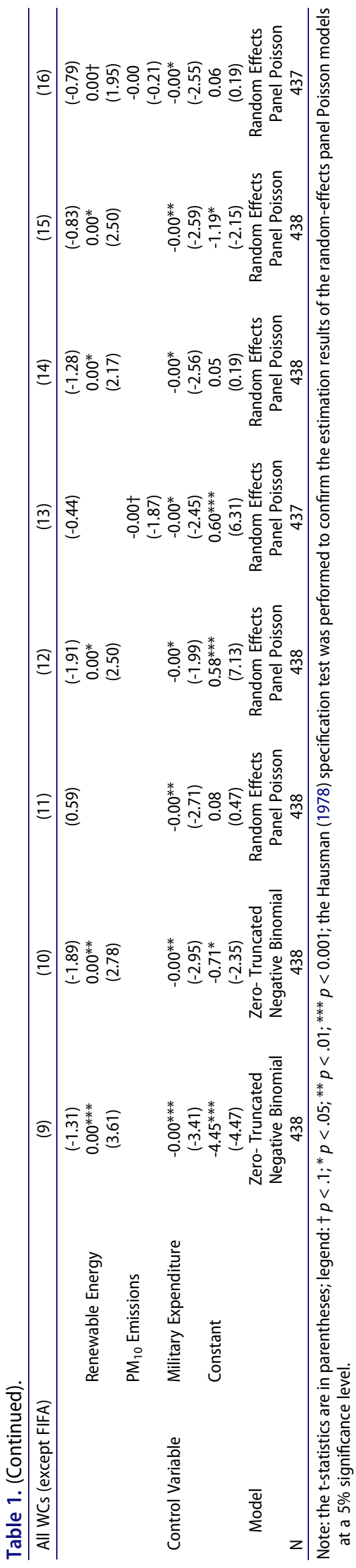

and properties and other related products, are traded between sporting event owners and stakeholders (Billings \& Eastman, 1998; Brown, 2000; Ferrand et al., 2012; McAuley \& Sutton, 1999; Parent \& Chappelet, 2016; Shoval, 2002; Tomlinson, 2005). In this market, most international sporting event owners tend to consider the financial interests of their commercial stakeholders, such as global broadcasting companies or sponsors. Accordingly, event owners tend to choose hosts based on the signaling of bidding countries' economic viability to maximize the financial profits of holding major sporting events. That is, they are most likely to award permission to host their events to countries that are economically attractive (Maennig \& Vierhaus, 2017). As a result, countries that are economically attractive may use their substantial tangible resources as part of marketing strategies for bids by promising economically profitable games to event owners.

Another finding of this paper is that economic and tangible factors are not the sole determinants of whether countries win permission to host major sporting events. More concretely, countries had greater success in international sporting event-bidding when they had high levels of human development and transparency as well as great sporting success. By contrast, countries were chosen to host such events less often when they had climates with high temperatures or generated a lot of air pollutants, such as $\mathrm{CO}_{2}$ or tiny particulate matter, in addition to generating little renewable energy. These results suggest that bidding to host international sporting events can be considered a global political arena embedded in a global society in which soft power factors, such as countries' socio-cultural and political characteristics, can affect bidding results via their relationship with Olympism (Lee \& Chappelet, 2012). In this context of soft power politics, event owners' choice of host countries can be influenced by non-economic factors or political motives. In other words, whether a bidding country has a good record regarding sustainable human development can be a key criterion when choosing a host site. Thus, event owners may choose hosts by considering the philosophy and principles of Olympism as they relate to the soft power of a bidding country to enhance their organizational legitimacy. Furthermore, event owners in Olympic sports, who are full-fledged members of the Olympic Movement in accordance with the Olympic Charter and must comply with the IOC guidelines on environmental protection and sustainable development as they relate to leaving a "green legacy" and making a positive social impact, may take into account the environmental record of a bidding country. As a result, they are more likely to award permission to host their sporting events to countries that are socially and environmentally 
attractive. In other words, countries that are socially and environmentally attractive may promote positive images of themselves as socio-culturally, politically, and environmentally advanced in marketing strategies to showcase themselves as ideal hosts for realizing/spreading the aims of Olympism and the Olympic Movement.

From a theoretical perspective, the empirical evidence on the relationship between country attractiveness and international sporting event-bidding success that is presented in this paper supports the explanatory power of both signaling theory (Spence, 1973) and soft power theory (Nye, 2004) in the context of international sports: on the one hand, the "signaling effect" of a country's economic attractiveness was mostly supported by the empirical results. According to signaling theory, bidding countries with well-developed markets send signals that imply promises to host profitable events to event owners. In turn, event owners tend to choose the most promising offer, i.e., a bid from a country with a strong economy that can bear the cost of hosting such an event and maximize the event owner's financial benefits. On the other hand, the "soft power effect" of a country's social and environmental attractiveness was also identified. According to soft power theory, bidding countries can exert soft power that includes cultural Affinity, political values, and legitimate foreign policies to appeal to and/or persuade event owners to award them permission to host their events. In such cases, event owners may choose the bidding country that has the most soft power from among several candidate countries that have similar degrees of economic attractiveness.

Lastly, the empirical results of the analysis presented in this paper suggest managerial and marketing implications for the organization of sporting events as well as the importance of country attractiveness as a prerequisite for successful sporting-event bidding in an international context. In other words, without a basic level of economic, social, and environmental attractiveness, a bidding country is less likely to win permission to host major international sporting events. Therefore, prospective event bidders, before the bidding phase, must assess their home countries' strengths/weaknesses in each dimension of country attractiveness. During the bidding stage, bidding organizations may develop and implement a variety strategies to improve the quality of their bids, including using lobbying tactics and promotional techniques to promote images of their countries as economically, socially, and environmentally attractive.

\section{Notes}

1. As event owners, international sport governing bodies organize international competitions, such as world or continental championships, and they allocate the hosting rights and related protected properties to event bidders. Thus, in the field of international sportevent bidding, event owners can be regarded as relevant stakeholders who are "any group or individual who can affect or is affected by the achievement of the organization's objective" (Freeman, 1984, p. 25).

2. Many sport consulting companies became specialized in the bidding process, and such companies are in charge of preparing bidding files, assisting bidders with communication campaigns, and lobbying for votes from the governing bodies (Diaey et al., 2011).

3. To test the soft power theory, the dataset starts in 1990, the first bidding year after the 1989 fall of the Berlin Wall.

4. The IOC establishes a hierarchy of sports, disciplines, and events. Thus, the term "sport," by IOC definition, refers to all the events that are sanctioned by one international sport federation, and each sport is subdivided into multiple disciplines that comprise several events for which medals are actually awarded in each competition.

5. Among the 33 core Olympic sports in the 2012 London Olympic Games, tennis was excluded from the sample because it has no equivalent to a world championship or the relevant bidding procedures.

6. The world championships in men's soccer, or the Fédération Internationale de Football Association (FIFA) World $\mathrm{Cup}^{\mathrm{m}}$, are excluded because bidding for megasports events, such as the Olympic Games and the FIFA World Cup, has different features from bidding for the other major (i.e., relatively smaller than mega) international sports events, such as the World Championships (Chappelet \& Lee, 2016). It is commonly agreed that hosting "expensive" mega-events like the Olympics and the FIFA World Cup requires more resources in terms of time and space, such as the preparation period, size, scale, scope, and so on. (Chappelet, 1996). Additionally, competitive pressure in bidding for the two mega-events is much higher than that for other medium and large-scale world championships.

7. Because sporting activities are highly interlinked with the natural environment in which a sport is performed, suitable environmental conditions, such as a mild climate, non-extreme temperatures, or even significant snowfall (Arne \& Maennig, 2012), are prerequisites for athletes to safely participate in sporting matches. As these events are tourism destinations that millions of spectators visit to experience vivid games, countries located in hot climates may be less likely to be selected as the hosts by event owners owing to heat-related problems in the venues.

8. Count data regression models in which the dependent variables are non-negative integers have been widely applied to various empirical fields (Hausman et al., 1984; Hellström \& Nordström, 2008; Jaggia \& Thosar, 1993; Nelson \& Young, 2008; Van der Heijden et al., 2003; Yang, 2007).

9. A frequently illustrated example in the econometrics literature is length of hospital stay counts for patients staying for at least one day.

10. Although the most basic event count model (i.e., a Poisson regression) is premised on the assumption that the probability of an event occurring at any instant is constant in period $i$ and is independent of all previous events during that observation period, this assumption 
is not plausible when past events may affect the likelihood of additional events occurring during a period. According to Balla (2000, p. 641), this type of dependence in event counts, which is manifested through overdispersion or inflated variance, can be accounted for by a negative binomial regression.

11. The dataset in this study is assumed to be chosen from a population of all kinds of international sporting events, which can be regarded as "panel" data according to Beck and Katz (1995) and Beck (2001). Panel data can be analyzed with either a fixed effects or a random effects model to avoid omitted variable bias and endogeneity problems because some unobserved variables can be differenced out of the regression and, thus, need not be measured. Based on the results of Hausman's (1978) specification test, this study uses a random effects model.

12. Several independent variables have high correlations, suggesting possible multi-collinearity (Gujarati, 2003, pp. 341-386) in the regression models. Thus, this study applies stepwise methods when performing each regression analysis.

13. However, it is interesting to find that market growth (i.e., the GDP growth rate) has no significant effect on bidding for major international sporting events like world championships. Conversely, faster economic growth, representing an emerging market, is essential for winning sporting mega-events, such as the Olympic Games (Lee \& Chappelet, 2012). This result suggests that event owners of relatively smaller world championships choose their host countries regardless of the level of economic growth, whereas mega-events owners, such as the IOC and FIFA, prefer countries with faster economic growth as hosts. One possibility explanation for event owners' different preferences for countries' economic standing relates to the need for the potential host of a mega-event to equip large-scale infrastructure and finance extensive budgetary support (Poast, 2007).

\section{Acknowledgments}

This paper is based on part of one of the authors' unpublished Ph.D. dissertation of the Swiss Graduate School of Public Administration, University of Lausanne, Switzerland.

\section{Funding}

This study was supported by a National Research Foundation of Korea grant from the Korean Government [NRF2017S1A3A2065838].

\section{References}

Akerlof, G. A. (1970). The market for "lemons": Quality uncertainty and the market mechanism. The Quarterly Journal of Economics, 84(3), 488-500. https://doi.org/10. 2307/1879431

Aminuddin, N. (2010). Establishing dimensions of country attractiveness for cross-border second homes. Journal of Tourism, Hospitality \& Culinary Arts, 2(2), 63-79. https:// citeseerx.ist.psu.edu/viewdoc/download?doi=10.1.1.675. $8536 \&$ rep $=$ rep $1 \&$ type $=$ pdf

Arne, F., \& Maennig, W. (2012). Determinants of successful bidding for mega events: The case of the olympic winter games. In W. Maennig \& A. Zimbalist (Eds.), International handbook on the economics of mega sporting events (pp. 70-84). Edward Elgar Publishing Inc.

Balla, S. J. (2000). Legislative success and failure and participation in rule making. Journal of Public Administration and Research Theory, 10(3), 633-654. https://doi.org/10.1093/ oxfordjournals.jpart.a024284

Bason, T., 2019. Every loser wins? Leveraging an olympic bid. Doctoral thesis (PhD), Manchester Metropolitan University.

Beck, N. (2001). Time-series-cross-section data: What have we learned in the past few years? Annual Review of Political Science, 4(1), 271-293. https://doi.org/10.1146/ annurev.polisci.4.1.271

Beck, N., \& Katz, J. (1995). What to do (and not to do) with time-series-cross-section data. American Political Science Review, 89(3), 634-647. https://doi.org/10.2307/2082979

Billings, A. C., \& Eastman, S. T. (1998). Marketing the olympics within the olympics. Ecquid Novi: African Journalism Studies, 19(2), 74-87. https://doi.org/10.1080/02560054. 1998.9653227

Brown, G. (2000). Emerging issues in olympic sponsorship: Implications for host cities. Sport Management Review, 3(1), 71-92. https://doi.org/10.1016/S1441-3523(00)70080-5

Cameron, A. C., \& Trivedi, P. K. (2009). Microeconometrics using stata. Stata Press.

Cantelon, H., \& Letters, M. (2000). The making of the IOC environmental policy as the third dimension of the olympic movement. International Review for the Sociology of Sport, 35(3), 294-308. https://doi.org/10.1177/10126900 0035003004

Chappelet, J.-L. (1996). Dimensions publiques et privées de l'organisation des Jeux olympiques. Revue économique et sociale, 54(3), 163-175. https://www.e-periodica.ch/digbib/ view?pid=res-001:1996:54::377\#188

Chappelet, J.-L. (2008). Olympic environmental concerns as a legacy of the winter games. The International Journal of the History of Sport, 25(14), 1884-1902. https://doi.org/10. $1080 / 09523360802438991$

Chappelet, J.-L. (2016). From olympic administration to olympic governance. Sport in Society, 19(6), 739-751. https://doi. org/10.1080/17430437.2015.1108648

Chappelet, J.-L. (2019). Beyond legacy: Assessing olympic games performance. Journal of Global Sport Management, 4(3), 236-256. https://doi.org/10.1080/24704067.2018.1537681

Chappelet, J.-L., \& Kübler-Mabbott, B. (2008). The international olympic committee and the olympic system: The governance of world sport. Routledge.

Chappelet, J.-L., \& Lee, K.-H. (2016). The emerging concept of sport-event-hosting strategy: Definition and comparison. Journal of Global Sport Management, 1(1-2), 34-48. https://doi.org/10.1080/24704067.2016.1177354

Chernushenko, D. (1994). Greening our games: Running sports events and facilities that won't cost the earth. Centurion Publishing \& Marketing.

Choi, C. J. (1999). Global competitiveness and national attractiveness. International Studies of Management \& Organization, 29(1), 3-13. https://doi.org/10.1080/ 00208825.1999 .11656754 
Diaey, T. D., Tjusevs, J. J., Pavels, Z., \& Garavelli, A. (2011). Bidding: How can you win even if you lose? Identifying the legacies of lost bids to host a sports mega event (pp. 89). CIES.

Dowse, S., \& Flechter, T. (2018). Sport mega-events, the 'nonWest' and the ethics of event hosting. Sport in Society, 21(5), 745-761. https://doi.org/10.1080/17430437.2018.1401359

Dreher, A. (2006). Does globalization affect growth? Evidence from a new index of globalization. Applied Economics, 38(10), 1091-1110. https://doi.org/10.1080/00036840500392078

Feddersen, A., Maennig, W., \& Zimmermann, P. (2008). The empirics of key factors in the success of bids for Olympic Games. Revue d'Économie Politique, 2(118), 171-187. https://doi.org/10.3917/redp.182.0171

Ferrand, A. (1993). La communication par l'événement sportif. In A. Loret (Ed.), Sport et management (pp. 280-294). Dunod.

Ferrand, A., Chappelet, J.-L., \& Seguin, B. (2012). Olympic marketing. Taylor and Francis (Routledge).

Ferrand, A., \& McCarthy, S. (2009). Marketing the sports organisation: Building networks and relationships. Routledge.

Freeman, R. E. (1984). Strategic management: A stakeholder approach. Pitman.

Gujarati, D. N. (2003). BASIC ECONOMETRICS (4th ed.). McGraw-Hill.

Hausman, J. A. (1978). Specification tests in econometrics. Econometrica, 46(6), 1251. https://doi.org/10.2307/1913827

Hausman, J. A., Hall, B. H., \& Griliches, Z. (1984). Econometric models for count data with applications to the patents R \& D relationship. Econometrica, 52(4), 909-938. https://doi. org/10.2307/1911191

Hellström, J., \& Nordström, J. (2008). A count data model with endogenous household specific censoring: The number of nights to stay. Empirical Economics, 35(1), 179-193. https://doi.org/10.1007/s00181-007-0155-0

Hilbe, J. (2011). Negative binomial regression (2nd ed.). Cambridge University Press.

Hoffmann, R., Ging, L. C., \& Ramasamy, B. (2002). Public policy and olympic success. Applied Economics Letters, 9(8), 545-548. https://doi.org/10.1080/13504850110102784

Hu, Y., \& Ritchie, J. R. B. (1993). Measuring destination attractiveness: A contextual approach. Journal of Travel Research, 32(2), 25-34. https://doi.org/10.1177/ 004728759303200204

International Olympic Committee (IOC). (2011). Olympic charter. Switzerland.

Jaggia, S., \& Thosar, S. (1993). Multiple bids as a consequence of target management resistance: A count data approach. Review of Quantitative Finance and Accounting, 3(4), 447-457. https://doi.org/10.1007/BF02409622

Kottek, M., Grieser, J., Beck, C., Rudolf, B., \& Rubel, F. (2006). World map of the Köppen-Geiger climate classification updated. Meteorologische Zeitschrift, 15(3), 259-263. https://doi.org/10.1127/0941-2948/2006/0130

Lee, K.-H. (2016). The conceptualization of country attractiveness: A review of research. International Review of Administrative Sciences, 82(4), 807-826. https://doi.org/10. $1177 / 0020852314566002$

Lee, K.-H. (2017). The olympics, soft power, and democratization: The role of bureaucracy. In I. Tobin (Ed.), The Experience of democracy and bureaucracy in South Korea (pp. 181-215). Emerald Publishing Limited.
Lee, K.-H., \& Chappelet, J.-L. (2012). Faster, higher, "Softly" stronger: The impact of soft power on the choice of olympic host cities. The Korean Journal of Policy Studies, 27(3), 47-71. https://s-space.snu.ac.kr/handle/10371/80021

Leonardsen, D. (2007). Planning of mega events: Experiences and lessons. Planning Theory \& Practice, 8(1), 11-30. https://doi.org/10.1080/14649350601158105

Li, M. (2009). Soft power: China's emerging strategy in international politics. Lexington Books.

Maennig, W., \& Vierhaus, C. (2017). Winning the Olympic host city election: Key success factors. Applied Economics, 49(31), 3086-3099. https://doi.org/10.1080/00036846.2016. 1254339

McAuley, A., \& Sutton, W. A. (1999). In search of a new defender: The threat of ambush marketing in the global sport arena. International Journal of Sports Marketing and Sponsorship, 1(1), 64-86. https://doi.org/10.1108/IJSMS-0101-1999-B006

McClory, J. (2010). THE NEW PERSUADERS: An international ranking of soft power. The Institute for Government.

Nelson, J. P., \& Young, D. (2008). Effects of youth, price, and audience size on alcohol advertising in magazines. Health Economics, 17(4), 551-556. https://doi.org/10.1002/hec.1273

Nye, J. (2004). Soft power: Means to success in world politics. Public Affairs.

Parent, M. M., \& Chappelet, J.-L. (2016). The handbook of sports event management. Routledge.

Peiser, B., \& Reilly, T. (2004). Environmental factors in the summer Olympics in historical perspective. Journal of Sports Sciences, 22(10), 981-1002. https://doi.org/10.1080/ 02640410400000298

Pentifallo, C., \& VanWynsberghe, R. (2012). Blame it on Rio: Isomorphism, environmental protection and sustainability in the Olympic Movement. International Journal of Sport Policy and Politics, 4(3), 427-446. https://doi.org/10.1080/ 19406940.2012.694115

Poast, P. D. (2007). Winning the Bid: Analyzing the international olympic committee's host city selections. International Interactions, 33(1), 75-95. https://doi.org/10.1080/ 03050620601157470

SCOTT, L. J., \& Jeremy, F. (2006). Regression models for categorical dependent variables using stata (2nd ed.). Stata Press.

Shoval, N. (2002). A new phase in the competition for the olympic gold: The London and New York Bids for the 2012 games. Journal of Urban Affairs, 24(5), 583-599. https://doi. org/10.1111/1467-9906.00146

Spence, A. M. (1973). Job market signaling. Quarterly Journal of Economics, 87(3), 355-374. https://doi.org/10.2307/ 1882010

Spence, A. M. (1974). Market signaling: Informational transfer in hiring and related screening processes. Cambridge, MA: Harvard University Press.

Tomlinson, A. (2005). The commercialization of the Olympics: Cities, corporations, and the Olympic commodity. In K. B. Wamsley \& K. Young (Eds.), Global olympics: Historical and sociological studies of the modern games (pp. 179-200). Elsevier.

Toohey, K., \& Veal, A. J. (2007). The olympic games: A social science perspective (2nd ed.). CABI.

Turner, D., \& McGillivray, D. (2018). Event bidding: Politics, persuasion and resistance. Routledge. 
Van der Heijden, P. G., Bustami, R., Cruyff, M. J., Engbersen, G., \& van Houwelingen, H. C. (2003). Point and interval estimation of the population size using the truncated Poisson regression model. Statistical Modelling, 3(4), 305-322. https://doi.org/10. 1191/1471082X03st057oa

Walters, G. (2011). Bidding for international sport events: How government supports and undermines national governing bodies of sport. Sport in Society: Cultures, Commerce, Media, Politics, 14
(2), 208-222. https://doi.org/10.1080/17430437.2011. 546520

World Commission on Environment and Development, 1987. Our common future (Report of the World Commission on Environment and Development). Oxford: Oxford University Press.

Yang, C.-H. (2007). What factors inspire the high entry flow in Taiwan's manufacturing industries-A count entry model approach. Applied Economics, 39(14), 1817-1831. https:// doi.org/10.1080/00036840600690181

\section{Appendix I}

Bid Wins of Countries in World Championships (1990-2012)

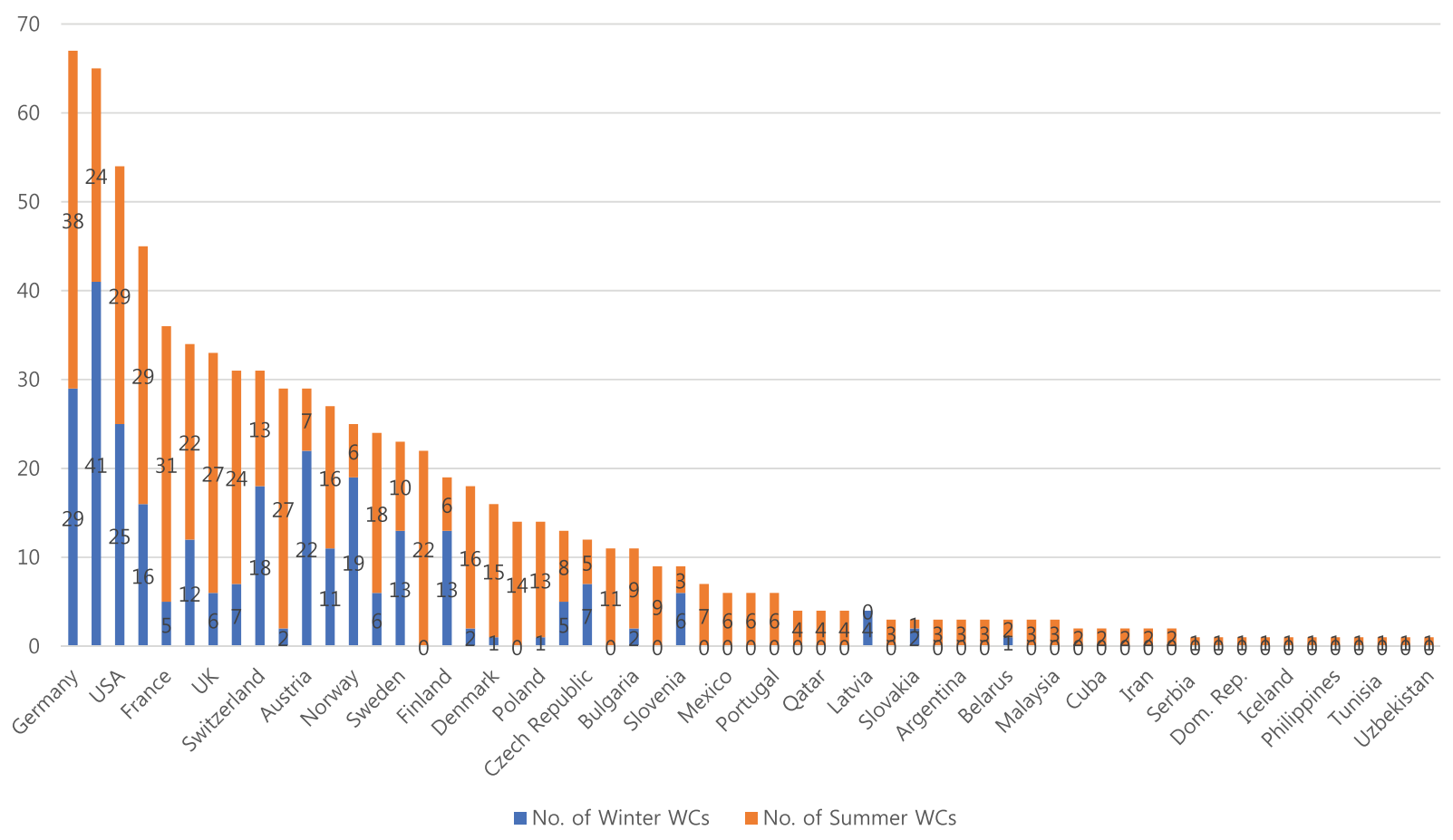

